\title{
Analysis on the Strategy of Constructing the Contemporary Ideological and Political Education System under Perspectives of Innovation and Career Occupation
}

\author{
Lin Wang ${ }^{1}$ \\ ${ }^{1}$ ChongQing College of Electronic Engineering, China.
}

\begin{abstract}
Keywords: Occupation Career; Political Education; Innovation; Ideological and Political.
\end{abstract}
\begin{abstract}
This paper analyzes the strategy of constructing the contemporary ideological and political education system under perspectives of innovation and occupation career. We believe that the process of ideological and political education is in fact the educator to educate the transmission of various theories, ideas and the educational activities of the educated people to transmit their ideological information to accept the activities of the link and the unity. In ideological and political education process should pass through the socialist core value system throughout, cannot make the socialist core value system stay in pursue of national level merely, but should the socialist core value system and individual contact. This paper proposes the new idea on the issues with the proper combination of the innovation and occupation career that is innovative.
\end{abstract}

\section{Introduction}

The ideological and the political education is a class or a certain political group, to achieve their political objectives and tasks, with purpose, in view of the influence of the ideology imposed on the people, in order to change people's thinking as a comprehensive education practice and make people healthy all-round development. We believe that the process of ideological and political education is in fact the educator to educate the transmission of various theories, ideas and educational activities of the educated people to transmit their ideological information to accept the activities of the link and the unity. In these two activities, the educational activities of pedagogue as the premise and condition that initiating the trainee comes to understand, but whether the ideological and political education goal can carry out finally, the key must lie in that the thought of trainee accepts the activity efficiency height.

Whether can effectively make the educated people to change their thinking and consciousness, which is the measure of the effectiveness of ideological and political education by the educator only criterion and requires us to carry out the teaching, we must determine the correct ideological and political education content, principles and methods from the following aspects. (1) Practicality is the essential attribute of ideological and political education. Because the subject and object of ideological and political education is people, it is a kind of spiritual communication activity based on the practice of educators and educators. From the educational process, the ideological and political education in fact is the process of the social personal character individuation and individual personal character socialization, but this process must be able to be completed through the practical process. (2) Practice plays a decisive role in the ideological and political education. This decision can be analyzed from four aspects: the source, the purpose, the power and the inspection standard. The aim of ideological and political education is to make the educational objects establish the scientific world outlook, as outlook on life and values, and enhance their ability to understand the world and transform the world. The correct object of education, world outlook, outlook on life and the formation of values, not rely solely on the teaching of knowledge and the results of speculation, but from the living reality of life.

Career planning of college students refers to the process of students' systematic career planning. It includes the study planning, career planning, love planning and the life planning. Occupational career planning and the quality of a direct impact on the quality of life in college, a more direct impact on employment or even future career success or failure. What narrow career refers to the development path of occupation and work duty that in a person life shoulders. What the generalized career refers to: 
that until withdraw from the complete career development process of occupation work from training, the choice occupation and employment acquisition and professional interest of occupational ability finally totally and the growth of human is the socialization that completes gradually, and the career development is person the important component of the psychologically healthy development. In the figure one, we show the contemporary ideological and political education for difference majors.

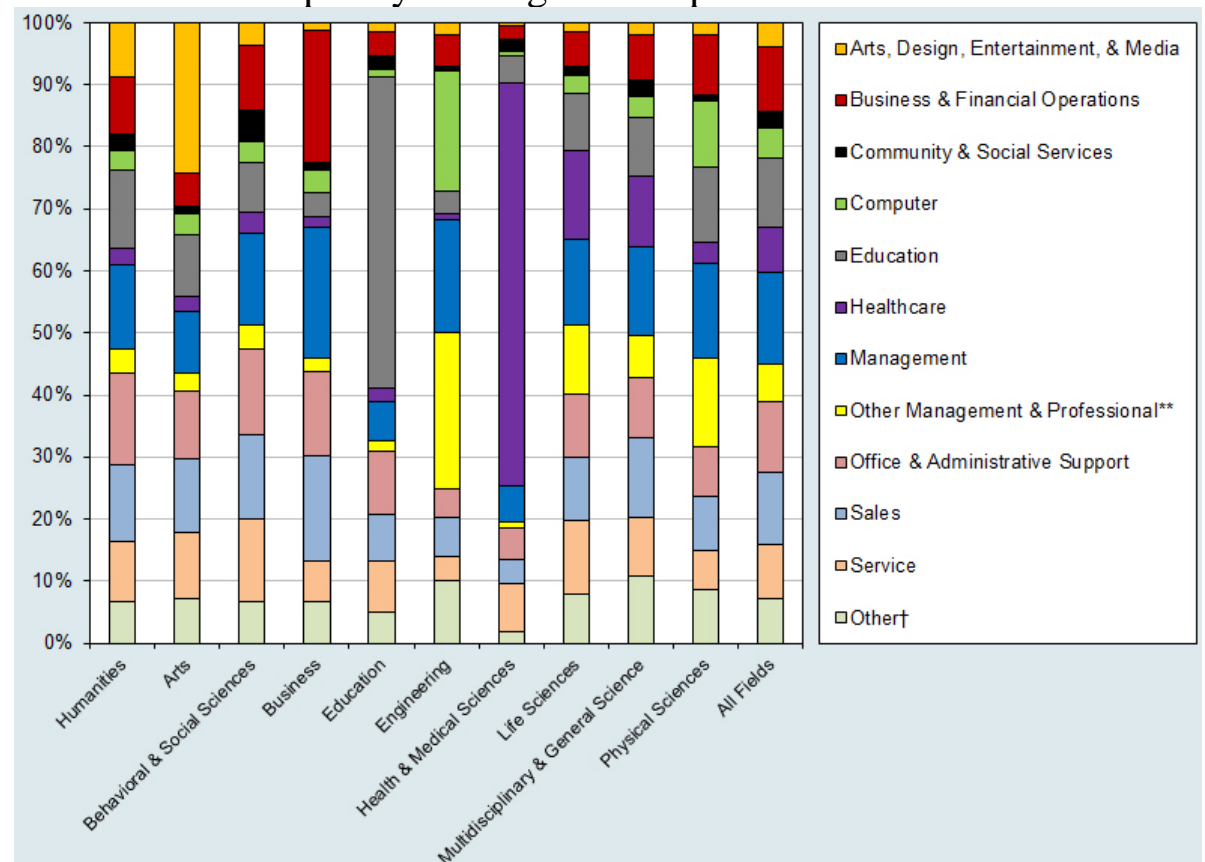

Fig. 1 Contemporary Ideological and Political Education for Difference Majors

\section{Our Proposed Methodology}

\subsection{The Massive Innovation Condition and Political Education System.}

Presently, our country entered the critical period and deepening reformation of the open attacking a fortified position time fully building a well-off society. A variety of general ideological and cultural interaction, people are affected by the impact of a variety of ideological and cultural channels, the problem of ideological and political education is increasing, the difficulty to increase. Under this basis we should then focus on the following aspects of innovations.

- In contemporary China, strengthens ideological and political education must first strengthen the theoretical system of the socialism with Chinese characteristics education, strengthens the scientific development concept education and insisted that with the scientific theory arming person, give full play to the base role and characteristics of the theoretical system of socialism with Chinese characteristics in ideological and political education.

- In the new era, strengthening the ideals and beliefs education is to strengthen the education of ideals and convictions of Marxism, the education of ideals and convictions of socialism with Chinese characteristics, to help people firmly believe in essential Marxism, to firmly believe in socialism, to take the road of the socialism with Chinese characteristics, and firmly trust the party and the people's government.

- We must fully the legitimate interest request that takes seriously the university student to grow to mature helping them solve by any means possible in various actual problems that studying, living and in getting employed comes across, encourages the university student, only then integrates to promote the time mighty current of the national development and in national revitalization individual growth progress that can be potential achievement truly as realizes the value and life pursuit.

Building a socialist harmonious society is to implement the scientific concept of development, to better promote China's economic and social development of the strategic initiatives. The construction of a socialist harmonious society is related to the fundamental interests of the overwhelming majority 
of the people, to the consolidation of the social basis of the party in power, to the historical task of the party, to the overall construction of a well-off society. Specifically, the historical process to grasp the rules is to have a correct understanding of ideological and political education, correct understanding of our impact on people's political thought of reform and opening up and development of the market economy, the correct understanding of the effects of changes in the international environment and the international political situation of people's political thought.

\subsection{Career Planning.}

Career planning theory is one of the important contents of western human resource management theory, which was originated in 60s, and was introduced to China from Europe and America in the middle of 90s. Professional career planning theory under this social background, and in the society actively seeks to solve under the university student employment problem way opportunity, entered the view of people, and started the attention of university employment department was introduced in the university student's career exploration gradually, became the theoretical foundation of the instruction university student professional career planning that was the important content of university student employment work system.

From the career planning perspective, we shall give the students some of the suggestions. (1) Increases the occupation experience to provide support for the university student. Lacking the present situation of occupation feeling and professional career in view of the university student, guiding the university student actively to put into the occupation practice, and simultaneously in guiding the university student participates in the social practice, should strengthen the pointedness and sense of purpose of occupation practice and will define oneself future effort direction that will strengthen the profession sensitivity. (2) Strengthen career education and help college students to establish the professional ideal. The school and whole society must help university student set up the correct professional career planning idea and education of general profession ideal, the career objective of formulation must and can unify with own professional disposition and interest that must realize the occupation ideal specific step and planning for action, and makes various efforts for this reason. (3) Strengthen the practice of career planning of college student self-consciousness. Along with the own knowledge and employment history rich and understanding to occupation deep level, as well as the society provides increase of employment opportunity, the university student after the formulation professional career planning should revise the profession goal, the action plan and profession strategy promptly that making it suit own actual situation, eventually achieves own lifelong goal.

Because the ability and quality of university student constantly is improving, social environment constantly are also changing, self-cognition, professional cognition as well as career objective also along with it change and adjustment. The dynamic and expansibility of career objective had decided newborn professional career planning education is heavy in setting up of professional career planning consciousness, professional career planning method grasps, as well as training of professional career planning ability, but is not only the preliminary hypothesis of career goal.

\subsection{Further Suggestions on the Contemporary Ideological and Political Education System.}

It is generally believed that the ideological and political education is an objective practice of the educational practice it plays an irreplaceable role in maintaining social stability, promoting economic development, heritage and development of some national culture, etc. Here, reason that this article mentioned this issue that was intends to stressed that the central party committee under the new historical conditions attached great importance to the ideological and political work, prominent humanist and practical significance of humane solicitude, for the purpose of completed the current ideological and political work comprehensively, for the basic task of that guarantee party smoothly realized and advances the economic society to be good and develop to provide the spiritual driving force and ideological safeguard quickly.

The ideological and political education person study research is the vivid practice of the Marxism person study theory, returns to the inevitable request of ideological and political education essence. From two's logical relation analysis, the Marxism person study is the revolution of person of study theory that is the elementary theory foundation of ideological and political education. Marx doctrine is the guiding ideology, theoretical basis and basic education content of the ideological and political 
education. The ideological and political education can promote the healthy development of its own only by adhering to the guidance of Marx's theory of human study. The philosophical thinking of the ideological and political education from the perspective of human studies, mainly from two aspects of Marx's theory of practice and the human nature: from the perspective of practice, the philosophy of the ideological and political education.

All in all, both in history and today's real society, the importance of the ideological and political education cannot be ignored its role cannot be replaced. The practice of revolution and construction has proved that all the progress of the work should be based on ideological progress should firmly grasp the central part of ideological education. From the foothold, the ideological and political education not only the society requests internalized the ideological concept, the moral rule that for the basic faith of educational subject, raises the political fiber and moral consciousness of educational subject, what is more important will be must facilitate the educational subject beyond the correct moral consciousness to change into the good moral ethics.

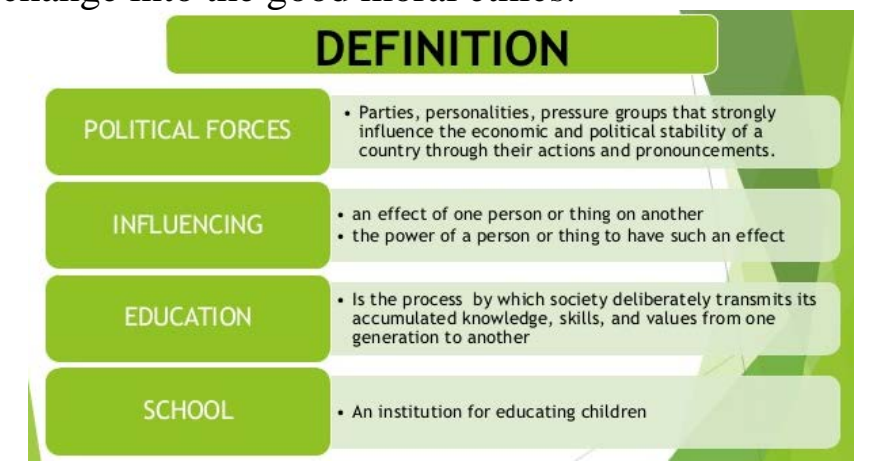

Fig. 2 Ideological and Political Education System Architecture

\section{Summary}

In this paper, we analyze the strategy of constructing the contemporary ideological and political education system under perspectives of innovation and occupation career. Ideological and political educators should make use of the educational factors in the various scenarios, in particular, they can consciously create educational contexts that influence and nurture people, and cultivate people's positive and some healthy thoughts and emotions imperceptibly so as to raise people's ideological consciousness and moral level the goal. The socialist core value system requests us to persist in taking the Marxism as the guiding principle, trains the outlook for honor and dishonor of student, enabling them to have the intense national spirit and spirit of the age. In ideological and political education process should pass through the socialist core value system throughout, cannot make the socialist core value system stay in pursue of national level merely, but should the socialist core value system and individual contact. This paper proposes the novel idea and perspective on the issue that will later help and assist the further development of the related theories.

\section{References}

[1]. Yonghong, Yi. "On the Value and Its Objective Definition of College Ideological and Political Education." The Science Education Article Collects9 (2013): 011.

[2]. Yang, Zhang. "In the view of network culture, ideological and political education of college students on the path of innovation." Journal of Jiamusi Education Institute 4 (2014): 039.

[3]. Xu, C. H. E. N. "The Inspiration of ZENG Guofan's Family Motto on College Students' Ideological and Political Education." Journal of Harbin University 6 (2013): 030.

[4]. Yu, Luo. "On the Interaction between Campus Culture and University Ideological and Political Teaching." The Science Education Article Collects 6 (2014): 009. 